\title{
Analysis of Self Esteem among Physical Education Professionals
} Dr. S. Saroja*

Assistant Professor, Alagappa University College of Physical Education, Alagappa University, Karaikudi Tamil Nadu, India

DOI: $10.36348 /$ jaspe.2020.v03i08.006

| Received: 30.07 .2020 | Accepted: 05.08.2020 | Published: 29.08.2020

*Corresponding author: Dr. S. Saroja

Abstract

Self-esteem is the basic human need or motivation. American psychologist Abraham Maslow for example included selfesteem in his hierarchy of needs for respect from others and inner self esteem. Respect from others entail recognition, acceptance, status and appreciation and was believed to be more fragile and easily lost than inner self esteem. According to Maslow, without the fulfillment of the self-esteem need, individuals will be driven to seek it and unable to grow and obtain self-esteem. The purpose of the study was to analyze the self-esteem between men and women physical education professionals. 17 women and 17 men undergoing Master of Physical Education students from Alagappa University College of Physical Education, Alagappa University, Karaikudi, Sivagangai district, Tamil Nadu were selected as subjects for the study at random. Self-esteem was measured by Self Esteem Inventory Scale by Dr. S. Karunanidhi (1996). The multidimensional questionnaire consists of 83 key items in the form of statements. It has both positive and negative items. The inventory measures six dimensions of self-esteem such as Competency, Global self-esteem, Moral and Self-control, Social esteem, Family self-esteem and Body and physical appearance. The data collected were statistically analyzed by using ' $t$ ' test to find out the significant difference between men and women physical education professionals on their self-esteem. The level of significance was fixed at 0.05 . The result showed that men scored in global self-esteem and social self-esteem than women. No significant difference was found in Competency, Moral and Self-control Family self-esteem and Body and physical appearance between men and women physical education professionals.

Keywords: Self Esteem, Physical Education Professionals.

Copyright @ 2020: This is an open-access article distributed under the terms of the Creative Commons Attribution license which permits unrestricted use, distribution, and reproduction in any medium for non-commercial use (NonCommercial, or CC-BY-NC) provided the original author and source are credited.

\section{INTRODUCTION}

Self -esteem is an important aspect of an individual's identity. It impacts a person deeply so much to impact his/her achievements and growth in various realms of life. Adolescence and young adulthood seems a very vulnerable age of impacting a person's self-esteem. The person is in the formative years of his/her self-concept and is experiencing manifold successes and failures in various realms of life. Social comparison is also quite high in these age groups. A Meta-analysis of definitions of self-esteem based on the work of various researchers has led to a holistic definition of self -esteem: It is the lived status of one's competence at dealing with the challenges of living in a worthy way over time. ${ }^{. e}[1]$. Global selfesteem or trait self-esteem, as it is relatively enduring across time and situations. Some researchers take a cognitive approach, and assume that global self-esteem is a decision people make about their worth as a person [2-4]. Others emphasize emotional processes, and define global self-esteem as a feeling of affection for oneself that is not derived from rational, judgmental processes [5, 6]. However it is defined, global selfesteem has been shown to be stable throughout adulthood, with a probable genetic component related to temperament and neuroticism [7].

\section{METHODS AND MATERIALS}

Seventeen women and Seventeen men undergoing Master of Physical Education students from Alagappa University College of Physical Education, Alagappa University, Karaikudi, Sivagangai district, Tamil Nadu in YMCA College of Physical Education were selected as subjects for the study at random. Selfesteem was measured by Self Esteem Inventory Scale by Dr. S. Karunanidhi [8]. The multidimensional questionnaire consists of 83 key items in the form of statements. It has both positive and negative items. The inventory measures six dimensions of self-esteem. 
- Competency -the ability to evaluate and understand one's personal resources

- Global self esteem -it is the general appraisal of the self

- Moral and Self control - is the reflection of feeling good as being honest, sincere, adhering to social values

- Social esteem - encompasses us as a friend to others

- Family self esteem- how we feel as a member of the family

- Body and physical appearance- is the body image as a contribution to a physical appearance and capabilities

\section{STATISTICAL PROCEDURE}

The data collected were statistically analyzed by using ' $t$ ' test to find out the significant difference between men and women physical education students on their self-esteem. The level of significance was fixed at 0.05

\section{RESULTS AND DISCUSSIONS RESULTS}

The results of study showed that there was a significant difference in intelligence between men and women physical education students.

Table -I: Showing Means, Standard Deviation, Mean Difference and Standard Error and Obtained 'T' Value on Self Esteem between Men and Women

\begin{tabular}{|c|c|c|c|c|c|c|}
\hline Subscales of self-esteem & Gender & Mean & SD & SED & MD & t-ratio \\
\hline \multirow{2}{*}{ Competency } & Men & 48.8 & 9.22 & 2.236 & \multirow{2}{*}{1.3} & \multirow{2}{*}{0.525} \\
\hline & Women & 47.5 & 4.27 & 1.037 & & \\
\hline \multirow[t]{2}{*}{ Global Self-esteem } & Men & 59.7 & 12.27 & 2.976 & \multirow{2}{*}{18.8} & \multirow{2}{*}{$5.395^{*}$} \\
\hline & Women & 40.9 & 7.42 & 1.8 & & \\
\hline \multirow[t]{2}{*}{ Moral self-control } & Men & 36.2 & 2.58 & 0.626 & \multirow{2}{*}{1.9} & \multirow{2}{*}{0.966} \\
\hline & Women & 34.2 & 7.87 & 1.909 & & \\
\hline \multirow[t]{2}{*}{ Social esteem } & Men & 39.4 & 5.66 & 1.372 & \multirow{2}{*}{12.7} & \multirow{2}{*}{$5.141^{*}$} \\
\hline & Women & 26.7 & 8.48 & 2.056 & & \\
\hline \multirow[t]{2}{*}{ Family Scale } & Men & 37.1 & 1.48 & 0.358 & \multirow{2}{*}{1.4} & \multirow{2}{*}{1.179} \\
\hline & Women & 35.7 & 4.5 & 1.091 & & \\
\hline \multirow[t]{2}{*}{ Body \& Physique } & Men & 30.3 & 7.24 & 1.755 & \multirow{2}{*}{0.8} & \multirow{2}{*}{0.27} \\
\hline & Women & 31.1 & 9.18 & 2.227 & & \\
\hline
\end{tabular}

Table I showed that the obtained t-ratio values on the Global self-esteem and Social esteem 5.395 and 5.141 were greater than the required table value of 2.037 at 0.05 level of significance with $2,32 \mathrm{df}$. Hence, the null hypothesis was rejected. There was a significant difference between men and women on Global self-esteem and Social esteem.
There was no significant difference found between men and women on Competency, Moral selfcontrol, Family scale and Body \& physique.

The means values on self-esteem sub scales are presented through bar diagram for better understanding of the results of this study in Figure I.

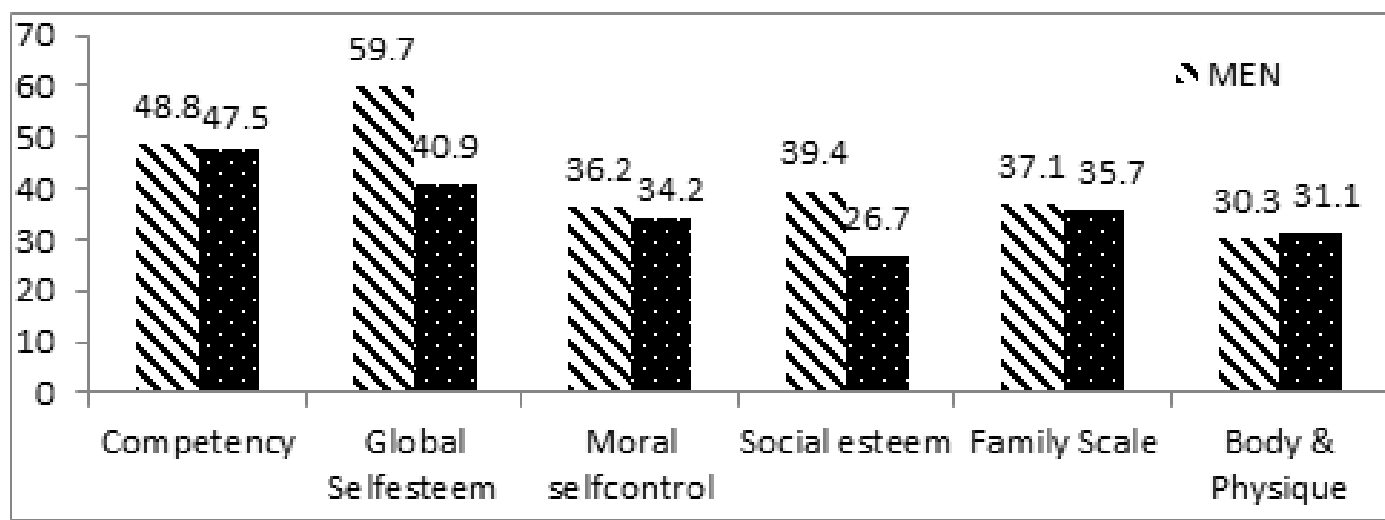

Fig-I: shows the mean values on Self-esteem subscales of men and women

\section{DISCUSSION}

Physical education men students scored higher than women in global self-esteem and this may be due to the reason that as cognitive approach men feels that they are much worth as a person which is not derived from rational, judgmental processes but has been shown to be stable throughout adulthood, with a probable genetic component related to temperament. 
In social self-esteem men outdo women because they feel comfortable and secure in their emotional and social relationships. It draws upon the their sense of happiness, of ease with self and own identity, quality of peer relationships and friendships, their sense of being valued, of social centrality, and of their joyful living especially at their college than women.

\section{CONCLUSION}

Based on the results and discussions of the present study, the following conclusions were drawn

1. It was concluded that there was significant difference between men and women physical education students in global self esteem and social self esteem

2. No significant difference was found between men and women on Competency, Moral self-control, Family scale and Body \& physique.

\section{REFERENCES}

1. Mruk, C. J. (2006). Self-esteem research, theory, and practice: Toward a positive psychology of self-esteem. Springer Publishing Company.
2. Coopersmith, S. (1967).The antecedent sofselfesteem. San Francisco: W. H. Freeman.

3. Crocker, J., \& Park, L. E. (2004). The costly pursuit of self-esteem. Psychological Bulletin, $130,392-414$

4. Crocker, J., \& Wolfe, C. T. (2001). Contingencies of self-worth. Psychological review, 108(3), 593.

5. Brown, T. J., Churchill Jr, G. A., \& Peter, J. P. (1993). Research note: improving the measurement of service quality. Journal of retailing, 69(1), 127.

6. Brown, M. A., Lindheimer, M. D., de Swiet, M., Assche, A. V., \& Moutquin, J. M. (2001). The classification and diagnosis of the hypertensive disorders of pregnancy: statement from the International Society for the Study of Hypertension in Pregnancy (ISSHP).

7. Neiss, M. B., Sedikides, C., \& Stevenson, J. (2002). Self- esteem: a behavioural genetic perspective. European Personality, 16(5), 351-367.

8. Karunanidhi, S. (2007). Skills in Adolescents and Adults with Intellectual Disabilities: Towards Independent Living within the Society. 